\title{
KEANEKARAGAMAN ENZIM INVERTASE, PENGEMBANGAN STRAIN UNGGUL DAN TEKNOLOGI PRODUKSINYA
}

\author{
Invertase Diversity, Novel Strain and Production Technology Development
}

\author{
Wilhelmus Terang Arga Sanjaya ${ }^{1}$, Giyanto ${ }^{2}$, Rahayu Widyastuti ${ }^{1}$, Dwi Andreas Santosa ${ }^{1 \star}$ \\ ${ }^{1}$ Prodi Bioteknologi Tanah dan Lingkungan, Departemen IImu Tanah dan Lingkugan, \\ Fakultas Pertanian IPB JIn. Ulin, Babakan, Kec. Dramaga, Bogor, Jawa Barat 16680. \\ ${ }^{2}$ Prodi Fitopatologi, Departemen Proteksi Tanaman, Fakultas Pertanian IPB \\ Jln. Kamper, Babakan, Kec. Dramaga, Bogor, Jawa Barat 16680 \\ *Email: dsantosa@indo.net.id
}

\begin{abstract}
Invertase or $\beta$-fructofuranosidase (E.C.3.2.1.2.6) have been a valuable enzyme in food industry, so that research about enhancing invertase activity on an industrial scale has been reported massively. So far, the production of the invertase enzyme is highly dependent on the potential activity of the invertase enzyme derived from microorganisms. The development of enzyme production technology is also a concern in invertase research to obtain an efficient and inexpensive production system. So far, various developments in enzyme production technology and enzyme utilization have been carried out, including various innovations in immobilizing and increasing the stabilization of the invertase enzyme during the production process. The development of superior strains and enzyme production technology continues amid the discovery of the latest approaches such as genetic engineering, protein modification, and nanotechnology. This paper aims to discuss invertase variation from various organisms, its correlation to novel microbial strain development to increase invertase production and invertase enzyme production technologies development including immobilization technology and stabilization of invertase enzymes.
\end{abstract}

Keywords: $\beta$-fructofuranosidase, ezyme production, fermentation, immobilitation, invertase gene

\begin{abstract}
ABSTRAK
Invertase atau $\beta$-fructofuranosidase (E.C.3.2.1.2.6) merupakan enzim yang sangat penting dalam dunia industri pangan sehingga berbagai optimasi aktivitas enzim untuk produksi dalam skala industri terus dilakukan. Produksi enzim invertase hingga sejauh ini sangat bergantung oleh potensi aktivitas enzim invertase yang diambil dari mikroorganisme. Selain itu, pengembangan teknologi produksi juga menjadi perhatian dalam pengembangan produksi dan pemanfaatan enzim untuk mendapatkan sistem produksi yang efisien dan murah. Sejauh ini berbagai pengembangan teknologi produksi enzim dan pemanfaatan enzim telah dilakukan, diantaranya dengan berbagai inovasi dalam melakukan imobilisasi dan peningkatan stabilisasi enzim invertase selama proses produksi. Pengembangan strain unggul dan teknologi produksi enzim terus dilakukan di tengah ditemukannya pendekatanpendekatan terkini seperti rekayasa genentika, modifikasi protein, dan teknologi nano. Artikel ini bertujuan untuk membahas variasi enzim invertase dari berbagai organisme, korelasi pengembangan strain mikrobia unggul terhadap peningkatan produksi enzim invertase, dan perkembangan teknologi produksi enzim invertase meliputi teknologi imobilisasi dan stabilisasi enzim invertase.
\end{abstract}

Kata Kunci: $\beta$-fructofuranosidase, fermentasi, gen invertase, imobilisasi, produksi enzim 


\section{PENDAHULUAN}

Industri enzim di pasar global bernilai 3,3 milyar USD pada 2010, 4,2 milyar USD di tahun 2014 dan diperkirakan nilai tersebut akan terus meningkat (Singh et al. 2016). Invertase atau $\beta$-fructofuranosidase (EC 3.2.1.26) merupakan enzim yang penting untuk diproduksi karena potensi dan manfaatnya terutama pada industri makanan dan minuman (Giraldo et al. 2012). Invertase merupakan salah satu enzim yang paling banyak digunakan pada industri makanan, khususnya dalam preparasi selai dan permen, karena fruktosa memiliki rasa yang lebih manis dan tidak mudah mengkristal dibandingkan dengan glukosa (Uma et al. 2010). Beberapa jenis invertase dengan aktivitas fructosy/transferase dapat dimanfaatkan dalam proses produksi fruktooligosakarida (FOS), gula dengan sifat prebiotik. Invertase juga digunakan dalam produksi madu artifisial dan obat-obatan serta pada industri kertas dan konstruksi elektroda untuk mendeteksi konsentrasi sukrosa (Lazar et al. 2011).

Peningkatan kualitas strain sangat diperlukan untuk menyediakan mikroorganisme penghasil enzim invertase dengan kemampuan yang tinggi untuk mendukung produksi enzim yang optimum (Veana et al. 2014). Usaha untuk meningkatkan kualitas produksi enzim dilakukan dengan melakukan eksplorasi novel enzyme yang memiliki aktivitas enzim yang lebih tinggi (Lin et al. 2019; Liu et al. 2020). Selain itu, pendekatan bioteknologi molekuler dan bioinformatika memiliki peranan yang sangat penting untuk memunculkan berbagai penemuan baru di bidang aplikasi enzim (Patel et al. 2017), khususnya berkaitan dengan produksi enzim rekombinan (Hua et al. 2018). Pengembangan enzim berbasis eksplorasi di alam tidak akan cukup untuk memenuhi tuntutan kebutuhan peningkatan produksi enzim yang dibutuhkan. Maka dari itu, pendekatan berbasis rekayasa genetika dengan aplikasi gen rekombinan sangat diperlukan untuk mendapatkan gen invertase yang memiliki aktivitas tinggi dalam mendegradasi gula (Nadeem et al. 2015).

Tantangan utama dalam pemanfaatan enzim di sektor industri adalah tingginya biaya produksi enzim itu sendiri (Jana et al.
2013). Pemanfaatan substrat dari bahan organik untuk produksi enzim saat ini menjadi penelitian yang menarik, seperti limbah agroindustri sebagai bahan baku yang murah dan banyak tersedia (Girelli et al. 2019). Hal tersebut bertujuan untuk memperoleh metode alternatif dalam produksi enzim dengan biaya rendah sekaligus untuk pengelolaan limbah. Limbah agro-industri secara umum dihasilkan dalam jumlah besar sepanjang tahun dan pemanfaatannya untuk produksi enzim memiliki keuntungan yaitu bersifat terbarukan, biaya rendah dan memiliki karakteristik berbeda-beda sehingga dapat disesuaikan untuk kebutuhan produksi enzim tertentu (Borghi et al. 2010). Optimasi produksi enzim dan aplikasinya juga sangat dipengaruhi oleh teknik purifikasi dan ekstraksi enzim tersebut. Berbagai pengembangan teknik ekstraksi enzim meliputi teknik ultrasound, microwave, dan enyme-assisted extraction dengan berbagai mekanisme yang berbeda (Marić et al. 2018).

Artikel ini bertujuan untuk membahas variasi enzim invertase dari berbagai organisme, korelasi pengembangan strain mikrobia unggul terhadap peningkatan produksi enzim invertase, dan perkembangan teknologi produksi enzim invertase meliputi teknologi imobilisasi dan stabilisasi enzim invertase.

\section{KERAGAMAN ENZIM INVERTASE}

Sistem tatanama untuk invertase adalah $\beta$-fructofuranosidase (EC 3.2.1.26), menunjukkan bahwa reaksi yang dikatalisasi oleh enzim ini adalah reaksi hidrolisis (Leal et al. 1999; Kulshrestha et al. 2013; Lorenzoni et al. 2014). Enzim invertase diketahui dapat diisolasi dari berbagai jenis mahluk hidup yang termasuk dalam three domain of life. Pengetahuan tentang sumber enzim invertase menjadi penting dikarenakan hal tersebut berkorelasi dengan perbedaan aktivitas enzim invertase itu sendiri. Enzim invertase dapat diisolasi dari mikroorganisme (bakteri, khamir, dan kapang) dan organisme tingkat tinggi seperti tanaman. Pancoast dan Junck (1981) menyatakan bahwa ragi Saccharomyces cerevisiae dan $S$. carlsbergensis merupakan sumber utama penghasil invertase untuk aplikasi industri. Berbeda dengan sebagian besar enzim, invertase memiliki aktivitas yang relatif tinggi pada kisaran $\mathrm{pH}$ yang luas antara 
3,5 sampai 5,5 , dengan aktivitas optimum pada $\mathrm{pH}$ 4,5. Aktivitas maksimum dicapai pada suhu $55^{\circ} \mathrm{C}$. Nilai Michaelis-Menten untuk jenis enzim yang berbeda bervariasi, tetapi kebanyakan enzim memiliki nilai $K_{m}$ (Konstanta Michaelis-Menten) antara 2-5 mM (Du et al. 2013). Aktivitas enzim didefinisikan sebagai kecepatan pengurangan substrat atau kecepatan pembentukan produk pada kondisi optimum. Satu unit aktivitas enzim didefinisikan sebagai satu mikromol ( $\mu \mathrm{mol} ; 10^{-6} \mathrm{~mol}$ ) substrat yang bereaksi atau produk yang dikatalisis setiap menit (Wang et al. 2017).

\section{Invertase dari tanaman}

Penelitian terkait invertase pada tanaman, telah dilakukan sejak akhir abad ke18. Kajian terkait invertase tanaman menunjukkan bahwa kelompok enzim invertase berperan penting dalam proses metabolisme tanaman, terutama berkaitan dengan metabolisme gula dan ketahanan tanaman terhadap cekaman abiotik (kekeringan, kemasaman) serta biotik (patogen). Penelitian terkait tanaman tebu sebagai bahan industri gula (sukrosa), melaporkan bahwa invertase berperan penting dalam proses akumulasi sukrosa pada batang yang mempengaruhi produksi gula. Metabolisme sukrosa sangat bergantung pada enzim yang terdapat di bagian internoda, seperti enzim invertase (INV, EC 3.2.1.26), sucrose synthase (SS, EC 2.4.1.13) dan sucrose phosphate synthase (SPS, EC 2.4.2.14). Pada tanaman, enzim invertase telah banyak dilaporkan sebagai kunci regulasi dari akumulasi sukrosa pada batang tebu. Dua kelompok enzim invertase seperti soluble acid invertase (SAI) dan netrual invertase (NI) dapat memecah sukrosa menjadi glukosa dan fruktosa (Pan et al. 2009; Chen et al. 2015). Neutral atau acid invertase ditemukan pada sitoplasma atau di dalam kompartmen metabolik sel, dan memiliki aktivitas yang rendah pada sel meristem (Wang et al. 2017). Pengembangan penelitian terkait enzim invertase pada tanaman dalam lima dekade terakhir terfokus untuk mengisolasi, mengkarakterisasi dan mengembangkan metode pengendalian aktivitas enzim di dalam jaringan tanaman. Sementara penelitian terkait bagaimana potensi enzim invertase dari tanaman untuk digunakan dalam kepentingan industri belum banyak dilakukan dibandingkan pemanfaatan enzim invertase dari khamir atau bakteri. Hal tersebut berpotensi untuk mendapatkan enzim invertase dengan aktivitas yang lebih tinggi meskipun dalam isolasi enzimnya relatif lebih sulit untuk dilakukan. Selain isolasinya yang lebih sulit, enzim invertase pada tanaman secara umum diketahui memiliki aktivitas yang beragam, bahkan di dalam satu spesies tanaman yang sama. Aktivitas tersebut ditentukan oleh berbagai faktor baik kondisi fisiologis tanaman, terutama maturasi dan faktor lingkungan, seperti suhu, $\mathrm{pH}$ dan serangan patogen. Tabel 1 menunjukkan berbagai penemuan aktivitas enzim invertase pada tanaman. Aktivitas tersebut diketahui dari $K_{m}$ (Konstanta Michaelis-Menten) dan $V_{\max }$ (kecepatan maksimum) dalam mendegradasi substrat (gula). Kemampuan tertinggi ditemukan pada Solanum tuberosum yang memiliki $K_{m}$ sebesar $133 \mathrm{mM}$ (invertase II) dan $K_{m}$ sebesar $128 \mathrm{mM}$ (solubilized invertase). Invertase pada tanaman kentang diketahui memiliki berbagai karakteristik aktivitas enzim, setidaknya ditemukan 4 enzim invertase dengan karakteristik yang berbeda. Meskipun memiliki aktivitas yang berbeda, enzim tersebut terindikasi sebagai enzim yang sama berdasarkan invertase elution pattern, dan pertepatan immunological recognition. Perbedaan aktivitas invertase disebabkan oleh perbedaan microenvironment dari enzim tersebut (Isla et al. 1999). Selain itu, aktivitas enzim invertase juga dipengaruhi oleh substrat yang digunakan. Isla et al. (1999) melaporkan bahwa invertase II memiliki nilai $K_{m}$ yang berbeda pada substrat yang berbeda. Enzim tersebut memiliki $K_{m} 133 \mathrm{mM}$ dengan substrat sukrosa, $K_{m} 187 \mathrm{mM}$ dengan substrat rafinosa, dan $K_{m} 230 \mathrm{mM}$ dengan substrat sukrosa dan fruktosa. Hal ini membuat penentuan aktivitas enzim invertase pada tanaman menjadi lebih kompleks, karena untuk melakukan hal tersebut perlu data yang komprehensif terkait microenvironment dari lokasi enzim invertase tersebut ditemukan di dalam sel atau jaringan tanaman. Perbedaan substat juga mempengaruhi tipe penghambatannya, pengunaan substrat sukrosa akan terjadi mekanisme penghambatkan non-kompetitif, sedangkan pengunaan fruktosa sebagai substrat akan menyebabkan penghambatan kompetitif. 
Tabel 1. Enzim Invertase dari tanaman

\begin{tabular}{|c|c|c|}
\hline Jenis Tanaman & Karakteristik Enzim & Referensi \\
\hline Ceri (Prunnus avium L.) & $\begin{array}{l}K_{m}=4 \mathrm{mM} \\
\text { degradasi sukrosa: } \\
0,9-3,8 \mu \mathrm{mol} \mathrm{mg}^{-1} \mathrm{~min}^{-1}\end{array}$ & (Krishnan and Pueppke 1990) \\
\hline Kentang (Solanum tuberosum) & $\begin{array}{l}\text { acid soluble invertase: } K_{m}=28 \mathrm{mM} \\
\text { invertase I: } K_{m}=20 \mathrm{mM} \\
\text { invertase II: } K_{m}=133 \mathrm{mM} \\
\text { solubilized invertase: } K_{m} 128 \mathrm{mM}\end{array}$ & $\begin{array}{l}\text { (Isla et al. 1999; Brummell et al. } \\
\text { 2011) }\end{array}$ \\
\hline Jagung (Zea mays) & $\begin{array}{l}\text { degradasi sukrosa: } \\
3 \mu \mathrm{mol} \mathrm{mg} \mathrm{min}^{-1}\end{array}$ & $\begin{array}{l}\text { (Billett et al. 1977; Kim et al. } \\
\text { 1999; Kim et al. 2000) }\end{array}$ \\
\hline $\begin{array}{l}\text { Stroberi (Fragaria ananassa Duch. } \\
\text { var. H6kowase) }\end{array}$ & - & (Ranwala et al. 1992) \\
\hline Tomat (Lycopersicon esculentum) & - & (Zhang et al. 2013) \\
\hline Populus (Golongan Aspirin) & - & (Chen et al. 2015) \\
\hline Arabidopsis thaliana & - & (Wang et al. 2017) \\
\hline Padi (Oryza sativa) & - & (Wang et al. 2017) \\
\hline Pisang (Musa cavendishii) & degradasi sukrosa: $1 \mu \mathrm{mol} \mathrm{mg}{ }^{-1} \mathrm{~min}^{-1}$ & (Sum et al. 1980) \\
\hline Tebu (Saccharum officinarum) & $\begin{array}{l}\text { acid soluble invertase: } K_{m}=55 \mathrm{mM} \\
\text { neutral invertase: } K_{m}=9,8 \mathrm{mM}\end{array}$ & $\begin{array}{l}\text { (Vorster and Botha 1998; } \\
\text { Hussain et al. 2009) }\end{array}$ \\
\hline
\end{tabular}

Tabel 2. Enzim Invertase dari Mikroorganisme

\begin{tabular}{|c|c|c|}
\hline Jenis Mikroorganisme & Karakteristik Enzim & Referensi \\
\hline Saccharomyces cerevisiae & $\begin{array}{l}K_{m}=11 \mathrm{mM} \\
V_{\max }=343,7 \mathrm{u} \mathrm{mg}^{-1}\end{array}$ & (Chand Bhalla et al. 2017) \\
\hline Candida utilis & $K_{m}=11 \mathrm{mM}$ (sukrosa); $150 \mathrm{mM}$ (rafinosa) & (Chavez et al. 1997) \\
\hline Candida guilliermondii Mpllla & 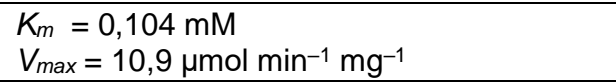 & $\begin{array}{l}\text { (Plascencia-Espinosa et } \\
\text { al. 2014) }\end{array}$ \\
\hline Aspergilus Niger AS0023 & $\begin{array}{l}K_{m}=35,67 \mathrm{mM} \\
V_{\max }=398 \mu \mathrm{mol} \mathrm{mL}^{-1} \mathrm{~min}^{-1}\end{array}$ & (Hocine et al. 2000) \\
\hline Rhodotorula glutinis & $\begin{array}{l}K_{m}=22,7 \mathrm{mM} \\
V_{\max }=0,096 \mu \mathrm{mol} \mathrm{min}^{-1} \mathrm{mg}^{-1}\end{array}$ & (Rubio et al. 2002) \\
\hline Neurospora crassa & - & (Metzenberg et al. 1963) \\
\hline Pyrococcus furiosus & $\begin{array}{l}K_{m}=12 \mathrm{mM} \\
V_{\max }=130 \mu \mathrm{mol} \mathrm{mL} \mathrm{min}^{-1} \mathrm{~min}^{-1}\end{array}$ & (Badra et al. 1994) \\
\hline Arthrobacter globiformis IFO 3062 & $\begin{array}{l}K_{m}=2,4 \mathrm{mM} \\
V_{\max }=127 \mathrm{~s} \\
\end{array}$ & (Win et al. 2004) \\
\hline Bacillus cereus TA-11 & $\begin{array}{l}K_{m}=370 \mathrm{mM} \\
V_{\max }=3,0 \mu \mathrm{m} \mathrm{min}{ }^{-1}\end{array}$ & (Yoon et al. 2007) \\
\hline Bifidobacterium breve UCC2003 & $\begin{array}{l}K_{m}=25 \mathrm{mM} \\
V_{\max }=24 \mu \mathrm{mol} \mathrm{min}-1\end{array}$ & (Ryan et al. 2005) \\
\hline Bifidobacterium infantis ATCC 15697 & $\begin{array}{l}V_{m} / K_{m}=0,65 \mathrm{dan} \\
0,025 \times 10^{-3} \mathrm{~min}^{-1} \mathrm{mg}^{-1}\end{array}$ & (Warchol et al. 2002) \\
\hline $\begin{array}{l}\text { Brevibacterium divaricatum NR RL B- } \\
2312\end{array}$ & $K_{m}=0,19 \mathrm{M}$ & (Yamamoto et al. 1986) \\
\hline Lactobacillus reuteri CRL 1100 & $\begin{array}{l}K_{m}=6,66 \mathrm{mM} \\
V_{\max }=0,028 \mu \mathrm{mol} \mathrm{min}^{-1}\end{array}$ & (Gines et al. 2000) \\
\hline Thermotoga neapolitana DSM 4359T & $K_{m}=5,2 \times 10^{8} \mathrm{M} \mathrm{s}^{-1}$ & (Dipasquale et al. 2009) \\
\hline
\end{tabular}

\section{Invertase dari mikroorganisme}

Perkembangan penelitian terkait enzim invertase pada mikroorganisme lebih banyak dilakukan pada kapang dibandingkan pada khamir dan bakteri, hal ini dikarenakan dari berbagai penelitian terakhir yang menunjukkan enzim invertase pada kapang memiliki tingkat afinitas yang relatif lebih tinggi dibandingkan pada bakteri dan khamir (Nadeem et al. 2015). Invertase pada fungi ditemukan dalam bentuk glikosilasi yang disekresikan dari sel, dan invertase 
intraselular dalam bentuk non-glikosilasi. Sekresi invertase umumnya berada dalam membran periplasma. Invertase ekstraselular terdiri dari dimer $270 \mathrm{kDa}$ dan mengandung $50 \%$ massa karbohidrat dalam bentuk 9 rantai oligosakarida mannosa dan setiap rantai berikatan dengan residu aspragin pada subunit polipeptida berukuran $60 \mathrm{kDa}$ (Heslot and Gaillardin 1992). Tabel 2 menunjukkan berbagai sumber enzim invertase yang telah diteliti. Invertase yang diisolasi dari mikrobia sebagian besar memiliki nilai $K_{m}$ antara 1-8 $\mathrm{mM}$. Nilai tersebut relatif rendah dibandingkan dengan rataan nilai $K_{m}$ yang dimiliki oleh tanaman. Meskipun nilai $K_{m}$-nya relatif rendah, nilai $V_{\max }$ yang dihasilkan oleh mikroorganisme, khususnya khamir relatif sangat tinggi. S. cerevisiae memiliki nilai $V_{\max }$ sebesar 343,7 $\mu \mathrm{mg}^{-1}$ dengan nilai $K_{m}$ sebesar $11 \mathrm{mM}$, sedangkan Aspergilus Niger AS0023 memiliki $V_{\max }$ sebesar $398 \mu \mathrm{mol} \mathrm{\textrm {min } ^ { - 1 }}$ $\mathrm{mg}^{-1}$ dengan nilai $K_{m}$ sebesar $35,67 \mathrm{mM}$. Nilai $V_{\max }$ menunjukkan tingkat kejenuhan enzim oleh substrat, sementara efisiensi katalis dari enzim ditunjukkan dari nilai $K_{m}$. Nilai $K_{m}$ didefinisikan sebagai konsentrasi substrat tertentu pada saat kecepatan katalitik enzim mencapai setengah kecepatan maksimumnya.

Meskipun pemanfaatan enzim invertase lebih banyak diisolasi dari kapang, penelitian terkait karakterisasi dan aktivitas enzim invertase dari bakteri, khamir dan tanaman masih terus dilakukan, terutama untuk mengetahui peran fisiologisnya di dalam jaringan tanaman. Hal tersebut memberikan data yang lebih komprehensif dari peran invertase dalam alur metabolisme tanaman, termasuk potensi aktivitas enzim invertase tanaman yang sering kali dilaporkan memiliki aktivitas yang lebih tinggi dibandingkan enzim yang diisolasi dari mikroorganisme (Tabel 1 dan 2). Meskipun dalam isolasi dan karakterisasinya relatif lebih kompleks, perkembangan keilmuwan pada bidang biologi molekuler saat ini memungkinkan hal tersebut untuk dilakukan secara lebih mudah. Perkembangan bioinformatika, biokimia dan genetika molekuler memungkinkan pemanfaatan enzim invertase dari tanaman menjadi lebih mungkin untuk dilakukan dan dikembangkan di masa saat ini.

\section{Struktur genetik enzim invertase}

Pemanfaatan teknologi biologi molekuler untuk pengembangan enzim invertase perlu didasari oleh pemahaman struktur gen invertase secara umum pada tanaman, dan informasi terkait region-region penentu yang berkorelasi dengan aktivitas enzim invertase. Secara umum, gen invertase merupakan faktor regulasi kunci dalam akumulasi sukrosa pada tanaman. Terdapat tiga tipe invertase, antara lain: neutral invertase yang terdapat pada sitoplasma, insoluble acid invertase yang ditemukan pada ruang dinding sel, dan soluble acid invertase yang ditemukan pada vakuola. Soluble acid invertase lebih banyak ditemukan aktif pada jaringan yang memiliki pertumbuhan cepat, seperti pada apikal akar dan internoda batang muda. Pada tanaman, soluble acid invertase, sangat aktif pada internoda muda dalam memecah sukrosa, dan aktivitasnya menjadi minimal pada internoda batang tua yang memiliki konsentrasi sukrosa relatif lebih tinggi. Meskipun penghambatan kerja enzim soluble acid invertase mampu meningkatkan akumulasi sukrosa pada suspensi sel tanaman tebu. Respon yang sama terbukti pada tanaman tebu yang sudah dewasa (Wang et al. 2013).

Cell wall invertase:

\begin{tabular}{|l|l|ll|}
\hline & & NDPN & WECPDF \\
\hline
\end{tabular}

Vacuolar invertase:

\begin{tabular}{c|c|cc|c|}
\hline & & NDPN & WECVDF & \\
\hline $\begin{array}{c}\text { signal } \\
\text { peptide }\end{array}$ & $\begin{array}{c}\text { N-terminal } \\
\text { propeptide }\end{array}$ & & $\uparrow$ & $\begin{array}{c}\uparrow \\
\text { mature } \\
\text { polypeptide }\end{array}$ \\
\end{tabular}

Gambar 1. Gen invertase (Fotopoulos 2005) 
Secara umum, cell wall invertase disintesis menjadi pre-proprotein dengan leader sequens yang panjang. Leader sequens tersebut akan diputus dalam proses transportasi dan maturasi protein. Leader sequens sebagian besar terdiri dari signal protein yang dibutuhkan untuk memasuki retikulum endoplasma dan menuju ke secretory pathway. Selain itu terdapat $N$ terminal propeptide yang berperan dalam stabilitas dan ikatan protein. Berkebalikan dengan cell wall invertase, vacuolar invertase memiliki pemanjangan C-terminal yang bersifat hidrofobik yang berukuran relatif lebih pendek (Fotopoulos 2005), (lihat Gambar 1).

Hubungan evolusi dengan aktivitas invertase

Sekuens DNA enzim invertase dari berbagai macam bakteri, khamir dan kapang telah dilaporkan dan tersedia di database sekuens. Alignment dan analisis filogenetik berbagai sekuens asam amino dari berbagai

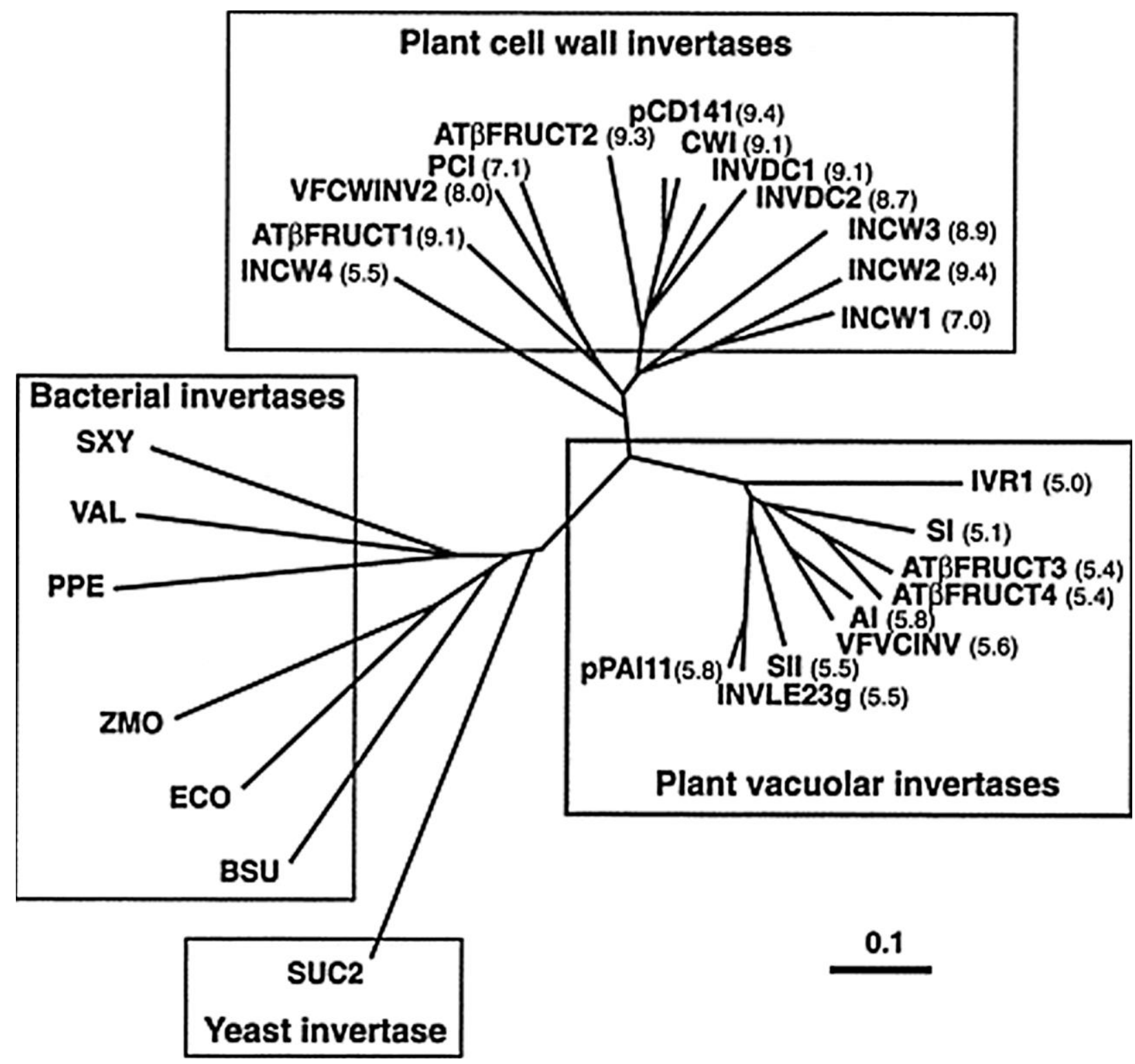

Gambar 2. Hubungan filogenetik antara sekuens enzim invertase (Kim et al. 2000). Keterangan: Sekuens Atbfruct1, Atbfruct2, Atbfruct3, Atbfruct4 (X74514, U11033, X95537, X97749) diisolasi dari Arabidopsis; VfVCINV, VfCWINV2 (Z49831, Z35163) diisolasi dari fava; InvDC1, InvDC2, sl, sll (M58362, X78424, X75352, X67163) diisolasi dari wortel; Ivr1, Incw1, Incw2, Incw3, Incw4 (U16123, U17695, AF050631, AF043346, AF043347) diisolasi dari jagung; pCD141, pPAl11 (Z22645, L29099) diisolasi dari kentang; Pcl (X85327) diisolasi dar ercis; CWI (X81834) diisolasi dari tembakau; Al (D10265) diisolasi dari mungbean; InvLe23g (Z12025) diisolasi dari tomat;. Sxy (X67744) dari Staphylococcus xylosus; Val (M26511) dari Vibrio alginolyticus; Ppe (L32093) dari Pediococcus pentasaceus; Zmo (D17524) dari Zymomonas mobilis; Eco (X81461) dari Escherichia coli; Bsu (X73124) dari Bacillus subtilis; Suc2 (Z46921) dari Saccharomyces cerevisiae 
spesies mikroorganisme yang berbeda mengungkapkan hubungan evolusioner di antara invertase yang dihasilkan mikrobia (Gambar 2). Ilustrasi lebih lanjut terkait perbedaan physiochemical dan karakteristik termodinamika enzim dari domain kehidupan (domain of life) berbeda, juga menunjukkan adanya variasi pada tingkat sekuens asam amino (Nadeem et al. 2015).

Pohon filogenetik menunjukkan kedekatan antara invertase yang dimiliki mikrobia (bakteri, khamir, dan kapang), sementara itu invertase yang dimiliki oleh organisme eukariotik lebih tinggi (tanaman) terklasifikasikan secara terpisah berdasarkan bagian conserve pada sekuensnya. Hampir semua sekuens enzim invertase mikroba memiliki GH32 yang merupakan family dari glycosyl hydrolases, dan juga termasuk ke dalam kelompok GHJ bersama dengan family GH68. Meskipun telah banyak dilakukan penelitian terkait protein crystal structure resolution, hanya sedikit dari enzim GH32 yang telah dimasukkan ke dalam database PDB. Sekuens-sekuens tersebut memiliki sekuens conserve, antara lain NDPNG, RDP, dan EC yang merupakan aspartate (D) didekat $\mathrm{N}$ terminus yang berperan sebagai nucleophile, dan glutamate $(\mathrm{E})$ yang berperan sebagai katalis asam atau basa (Nadeem et al. 2015).

Perbedaan sekuens gen enzim invertase antar domain kehidupan berkorelasi dengan perbedaan aktivitas enzim tersebut. Guo et al. (2018) menyatakan bahwa enzim invertase pada kapang mengindikasikan tingkat afinitas untuk gula yang relatif lebih tinggi dibanding sebagian besar enzim invertase yang dipurifikasi khamir (yeast) dan bakteri.

Sekuens enzim invertase pada tanaman, dengan mengesampingkan asal enzim tersebut dari tanaman monokotil atau dikotil, dibagi menjadi cell wall bound invertase dan vacuolar invertase, berbeda dengan invertase pada kapang dan bakteri. $\mathrm{Kim}$ et al. (2000) melakukan dan membuktikan hal tersebut melalui konstruksi pohon filogenetik untuk enzim invertase INCW3 dan INCW4. Keduanya menunjukkan kedekatan hubungan evolusi yang relatif lebih dekat dari pada vacuolar invertase, termasuk vacuolar invertase yang ditemukan pada jagung (IVR1). Hal tersebut mengindikasikan bahwa gen enzim invertase mengalami perkembangan evolusi divergen antara cellwall bound dan vacuolar invertase. Meskipun demikian, INCW3 dan INCW4 invertase termasuk ke dalam sub-klas yang berbeda. INCW3 invertase adalah sub-klas yang sebagaian besar merupakan family cell wall bound invertase pada jagung, sementara itu INCW4 invertase tidak termasuk ke dalam sub-klas mana pun.

Konstruksi filogenetik akhirnya mengacu pada penggolongan enzim invertase yang ditemukan pada tanaman. Penggolongan tersebut didasarkan pada lokasi dan derajat keasaman optimum. Berdasarkan lokasi ditemukannya, enzim invertase kemudian digolongkan menjadi CWINs (Cell wall invertases), VINs (Vacuolar invertases), dan CINs/ Cytoplasmic invertases. Sedangkan berdasarkan derajat keasaman optimum, invertase dibagi menjadi neutral atau alkaline invertase (CINs/ Cytoplasmic invertases) dan acid invertase. CWINs (Cell wall invertases) dan VINs (Vacuolar invertases) dari alga hijau termasuk dalam sub-group $\mathrm{G}$, sementara itu acid invertase dari tanaman lebih tinggi dimasukan ke dalam sub-group A-F. Di sisi lain, Neutral atau Alkaline invertase (CINs/ Cytoplasmic invertases) yang berasal dari alga hijau dan tanaman lain dimasukkan ke dalam sub-group yang sama, yaitu grup $\alpha$ dan $\beta$ (Wan et al. 2018).

Konstruksi filogenetik dari enzim invertase yang telah berhasil diisolasi dari berbagai spesies menunjukkan bahwa adanya perbedaan enzim invertase dari tanaman dan dari mikroorganisme (bakteri, khamir, dan kapang) yang keduanya membentuk dua kelompok besar tersendiri. Hal tersebut menunjukkan bahwa adanya perbedaan urutan basa nukleotida yang relatif tinggi antara enzim invertase mikroorganisme dan tanaman, sehingga berpotensi menghasilkan aktivitas invertase yang berbeda. Berdasarkan dari percabangan yang dibentuk, kelompok enzim invertase dari tanaman memiliki variasi yang relatif lebih beragam dibandingkan dengan mikroorganisme, sehingga karakterisasi enzim invertase menjadi sangat penting. Variasi tersebut berhubungan dengan fungsi spesifik dari enzim invertase dalam jaringan tanaman. Variasi yang tinggi menunjukkan bahwa enzim invertase dimungkinkan bekerja optimal pada kondisi yang beragam pada 
jaringan tanaman. Faktor-faktor tersebut bisa jadi menguntungkan ataupun sebaliknya dalam pemanfaatannya.

\section{FAKTOR PENENTU KINERJA INVERTASE}

Aktivitas enzim invertase ditentukan dari kemampuannya mendegradasi gula, seperti sukrosa, rafinosa, dan fruktosa. Laju degradasi dipengaruhi oleh beberapa faktor, antara lain suhu, pH, lama pemanasan, konsentrasi substrat dan konsentrasi enzim (Perez et al. 2019). Laju degradasi sukrosa dapat diperlambat atau bahkan dihambat dengan penambahan inhibitor (Patel et al. 2017). Peningkatan suhu pada reaksi enzim memiliki dua pengaruh yang tidak seimbang. Pengaruh tersebut adalah peningkatan laju reaksi dan di sisi lain dapat menyebabkan inaktivasi enzim. Aktivitas enzim invertase meningkat secara perlahan dengan kenaikan suhu. Suhu maksimum aktivitas invertase adalah $60^{\circ} \mathrm{C}$, peningkatan suhu lebih lanjut menyebabkan penurunan laju degradasi sukrosa (Rahman et al. 2004). Morsy dan Ibrahim (2016) melaporkan bahwa enzim invertase dapat menjalankan reaksi optimal pada suhu tinggi hingga $50^{\circ} \mathrm{C}$, namun hanya terjadi pada periode reaksi pendek dikarenakan kestabilan enzim yang rendah. Pada perode reaksi panjang, enzim tidak lagi aktif pada suhu tinggi. Invertase pada $S$. cerevisiae memiliki aktivitas yang tinggi dan stabilitas yang baik pada suhu $35^{\circ} \mathrm{C}$. Invertase memberikan aktivitas maksimum pada $\mathrm{pH} 7,2$. Aktivitas turun perlahan pada $\mathrm{pH}$ asam, tetapi turun secara cepat pada $\mathrm{pH}$ basa. Observasi ini menunjukkan bahwa enzim relatif stabil pada kisaran $\mathrm{pH}$ asam sampai $\mathrm{pH}$ netral. Nilai $\mathrm{pH}$ optimum invertase dari benih padi adalah 7,0 (Rahman et al. 2004). Li et al. (2018) menjelaskan bahwa invertase pada umumnya akan mengalami degradasi pada $\mathrm{pH} 4,0$. Acid invertase pada umumnya memiliki kemampuan optimum pada $\mathrm{pH} 5$ daripada $\mathrm{pH}$ netral. Wang et al. (2013) menyatakan bahwa perubahan pada laju reaksi enzim oleh $\mathrm{pH}$ mungkin dapat disebabkan oleh tiga faktor, antara lain: protonasi sisi aktif rantai asam amino pada kompleks enzim-substrat (ES) berubah, menghasilkan perubahan kemampuan ES dalam menghasilkan produk, perubahan muatan ion pada molekul substrat atau sisi aktif enzim yang dapat mengubah kecenderungan dari dua molekul tersebut untuk membentuk kompleks ES, dan perubahan $\mathrm{pH}$ dari netral dapat melemahkan stabilitas protein, mempercepat denaturasi enzim yang bersifat irreversible.

Invertase dapat mengkatalisis reaksi hidrolisis sukrosa pada konsentrasi diatas $59 \% \mathrm{wt} / \mathrm{vol}$. Peningkatan konsentrasi sukrosa lebih lanjut sampai $80 \%$ wt/vol menurunkan aktivitas enzim secara signifikan. Hal tersebut juga dipengaruhi oleh konsentrasi air rendah, inhibisi oleh substrat atau agregasi substrat (Fils-lycaon et al. 2011; Xue et al. 2018). Brown (1902) melakukan penelitian tentang invertase, menyatakan bahwa jika konsentrasi sukrosa lebih tinggi daripada konsentrasi enzim, kecepatan reaksi menjadi tidak tergantung pada konsentrasi sukrosa. Aktivitas enzimatik akan menurun pada konsentrasi substrat yang tinggi dan cenderung membentuk asimtot. Jenis penghambatan ini akan membentuk kompleks (dead end complex), satu sisi molekul substrat terikat pada enzim dan molekul substrat lain terikat pada sisi lain (sekunder) enzim (Rahman et al. 2001).

\section{PRODUKSI INVERTASE DAN OPTIMASINYA}

Peranan enzim invertase dalam industri sangat penting dalam pembuatan permen dan fondant. Selain itu, enzim invertase juga digunakan dalam high test molasses (Veana et al. 2014). Invertase yang mengkatalis hidrolisis sukrosa dimanfaatkan dalam industri makanan sebagai humectant dalam persiapan permen, krim non-kristalisasi, selai, dan madu buatan (Taskin et al. 2013). Produksi enzim invertase pada umumnya memanfaatkan peran khamir (Saccharomyces) dalam proses produksinya. Secara umum, tahapan produksi enzim antara lain: skrining untuk mendapatkan peningkatan aktivitas enzim atau mendapatkan novel enzymes, seleksi mikroorganisme dan peningkatan strain, fermentasi untuk produksi enzim, purifikasi enzim, dan formulasi enzim (Patel et al. 2017).

Optimasi produksi enzim sangat penting agar proses produksi dapat berjalan secara efisien. Optimasi dapat dilakukan pada setiap tahap, terutama tahap fermentasi untuk produksi enzim dikarenakan proses fermentasi sangat dipengaruhi oleh berbagai 
faktor lingkungan (suhu, kadar air awal, waktu inkubasi, aerasi, dan ketersediaan nutrisi pada substrat) dan penting untuk mendapatkan kondisi optimum untuk proses produksi (Carneiro et al. 2011; Aita et al. 2019). Selain itu, tahap purifikasi enzim juga sangat penting untuk mengoptimalkan proses pemisahan enzim dengan substratnya. Hal ini dikarenakan kemurnian enzim sangat mempengaruhi kualitas enzim yang diproduksi. Tahap purifikasi dapat dilakukan dengan berbagai metode antara sentrifugasi, microfiltration, gel filtration dan kromatografi. Tahap purifikasi secara umum adalah dengan menghancurkan sel, presipitasi dan klarifikasi, sentrifugasi dan filtrasi, hingga pemurnian tahap akhir sebelum dilakukan pengeringan (Patel et al. 2017).

Metode fermentasi yang umum digunakan dalam produksi invertase yaitu Solid State Fermentation (SSF) dan Submerged Fermentation (SmF). Perbedaan mendasar antara kedua metode fermentasi ini adalah tingkat kadar air pada media. Fermentasi dengan metode SSF berlangsung pada substrat padat dengan kadar air yang relatif rendah (Alegre et al. 2009). SSF lebih cocok digunakan di negara-negara berkembang dikarenakan lebih hemat biaya (Khootama et al. 2018), konsumsi air yang lebih rendah, mengurangi biaya pengolahan air limbah dan konsumsi energi yang lebih rendah, tingkat produktivitasnya tinggi, tekniknya sederhana, recovery produknya lebih baik, dan busa yang terbentuk sedikit (Kulshrestha et al. 2013; Leite et al. 2019; Molaverdi et al. 2019). Substrat padat pada metode SSF tidak hanya menyediakan nutrien bagi kultur tetapi juga sebagai tempat penyimpanan air untuk sel mikrobia (Aranda et al. 2006). Akan tetapi, sistem SSF memiliki kelemahan dimana transfer massa dan panas tidak sebaik substrat cair (Nguyen et al. 2016; Molaverdi et al. 2019). Kedua proses tersebut memanfaatkan mikrobia untuk memproduksi enzim yang mengkatalis reaksi yang kesesuaiannya dipengaruhi oleh efisiensi pertumbuhan mikrobia dan produksi enzim itu sendiri (Aita et al. 2019). Meskipun penelitian terkait efektivitas sistem SSF dan SmF telah dimulai di tahun 1980an, pengembangan produksi enzim terus dilakukan hingga saat ini. Hal ini dikarenakan pengunaan substrat dan strain mikrobia yang berbeda sangat berpengaruh terhadap tingkat optimasi produksi enzim yang dapat dicapai (Aita et al. 2019; Singh et al. 2020). Pada penelitianpenelitian sebelumnya, produksi invertase tertinggi didapatkan dari hasil fermentasi limbah buah-buahan dengan mengunakan strain Aspergillus flavus yakni $25,8 \mathrm{IU} \mathrm{mL}^{-1}$ (Uma et al. 2010; Chand Bhalla et al. 2017).

Penelitian tekait komposisi medium untuk produksi enzim invertase terus dilakukan saat ini dengan tujuan mengoptimalkan berbagai limbah untuk menekan biaya produksi. Berbagai limbah telah dilaporkan berpotensi untuk digunakan dalam proses produksi enzim invertase. Kulit buah-buahan (jeruk, delima, nanas) merupakan salah satu limbah yang sering digunakan untuk produksi enzim invertase (Uma et al. 2012, Raju et al. 2016). Selain itu pemanfaatan molase juga digunakan dalam produksi enzim invertase. Komposisi jenis gula yang terkandung dalam medium subtrat sangat berpengaruh terhadap aktivitas enzim invertase. Raju et al. (2016) melaporkan bahwa komponen disakarida sukrosa dan fruktosa berpegaruh paling tinggi terhadap aktivitas enzim invertase dibandingkan dengan gula lainnya. Selain itu, keberadaan beberapa ion juga sangat berpegaruh terhadap aktivitas invertase. Aktivitas invertase akan meningkat sebesar $\mathrm{K}^{+}$dan $\mathrm{Ca}^{+2}$ tetapi beberapa ion termasuk $\mathrm{Mn}^{+2}$, $\mathrm{Cu}^{+2}, \mathrm{Hg}^{+2}, \mathrm{Mg}^{+2}$, dan $\mathrm{Zn}^{+2}$ mencegah aktivitas invertase (Oyedeji et al. 2017; Manoochehri et al. 2020). Raju et al. (2016) melaporkan penambahan $\mathrm{NaCl}, \mathrm{KCl}, \mathrm{CaCl}$, dan EDTA masing-masing meningkatkan aktivitas enzim invertase.

\section{Strain unggul dan rekayasa genetika}

Produksi enzim sangat berkaitan dengan kualitas strain mikroba yang digunakan dalam proses produksi enzim (Wan et al. 2010). Mikrobia yang banyak digunakan dalam berbagai produksi enzim invertase merupakan fungi, hal ini dikarenakan fungi cenderung memiliki kemampuan produksi enzim lebih tinggi dibandingkan bakteri. Meskipun demikian, pengembangan produksi enzim invertase menggunakan strain bakteri terus dilakukan. Awad et al. (2013) telah melaporkan pengunaan bakteri Lactobacillus brevis Mm- 6 yang diisoalsi dari ASI (air susu ibu) dan mengembangkan strategi optimasi berbasis pendekatan statistik untuk memperoleh 
konsentrasi substrat yang optimum. Pengunaan L. brevis yang diisolasi dari ASI dinilai lebih aman dalam pengembangan produksi enzim invertase. Hoffmann et al. (2020) mengunakan beberapa strain Gluconobacter dan mendapatkan hasil aktivitas invertase yang tinggi pada $G$. japonicus LMG 26773 dan G. oxydans dalam pengembangan keto-fructose sebagai pemanis buatan alternatif.

Berbagai penelitian terkait peningkatan produksi enzim invertase pada fungi telah banyak dilakukan. Hasil penelitian Ohara et al. (2015) menunjukkan bahwa penggunaan desain formulasi substrat menggunakan limbah agro-industri berbeda untuk produksi invertase oleh $A$. niger LBA 02 dengan metode SSF merupakan suatu strategi efektif untuk meningkatkan produksi enzim. Sebelumnya, Romero-Gomez et al. (2000) memproduksi invertase dengan substrat residu kedelai menggunakan $A$. niger strain C28B25 menghasilkan aktifitas enzim sebesar $180 \mu \mathrm{m} \mathrm{L}^{-1}$. Alegre et al. (2009) meneliti produksi enzim oleh $A$. niveus menggunakan ampas tebu sebagai sumber karbon dan dilaporkan aktivitas enzim sebesar 3,9 $\mu \mathrm{m} \mathrm{g}^{-1}$. Alegre et al. (2009) mengevaluasi potensi limbah industri berbeda sebagai substrat untuk produksi invertase dengan $A$. caespitosus dan melaporkan nilai aktivitas enzim tertinggi diperoleh pada substrat sekam gandum. Rustiguel et al. (2010) melaporkan produksi invertase dengan $A$. phoenicis yang mampu meningkatkan level produksi enzim hingga

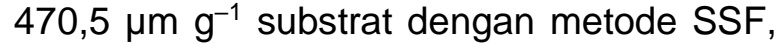
menggunakan kacang kedelai sebagai sumber karbon. Alves et al. (2013) melaporkan bahwa produksi invertase dengan $A$. nidulans menggunakan tepung gandum hitam sebagai substrat setelah dilakukan optimasi medium dengan respon permukaan, aktivitas enzim meningkat secara spesifik mencapai $>250 \mu \mathrm{m} \mathrm{g}^{-1}$. Oyedeji et al. (2017) melaporkan bahwa $A$. niger IBK1 memiliki kemampuan produksi invertase yang tinggi dengan mengunakan substrat limbah nanas pada kondisi cenderung asam. Chand Bhalla et al. (2017) melaporkan produksi enzim invertase menggunakan strain S. cerevisiae SAA-612 yang diisolasi dari minuman beralkohol tradisional Himachal Pradesh. Pengunaan pendekatan respons permukaan untuk mengoptimalkan kondisi kultur dapat meningkatkan produksi invertase hingga 24 kali lipat. Taskin et al. (2016) mengembangkan produksi enzim invertase dalam kondisi non-steril pada suhu rendah untuk pertama kalinya dengan mengunakan strain Cladosporium herbarum ER-25. Pengembangan produksi enzim pada suhu rendah dapat mencegah terjadinya kontaminasi bakteri lain yang sebagian besar merupakan bakteri mesofilik dan thermofilik (Ruan et al. 2010; Cabrera dan Blamey 2018; Ebaid et al. 2019). Pengunaan lebih dari satu strain yang memiliki sifat yang berbeda dapat digunakan untuk meningkatkan aktivitas enzim, seperti pengunaan Ascomycetes dan Basidiomycetes pada satu sistem fermentasi (Rodrigues et al. 2020).

Pengembangan aplikasi enzim invertase sangat bergantung pada pengembangan strain mikroorganisme yang digunakan dalam proses produksi enzim. Terlepas dari usaha untuk menemukan strain mikrobia yang mampu mendukung produksi enzim secara optimal, peningkatan kualitas strain sangat diperlukan untuk menyediakan mikroorganisme penghasil enzim invertase dengan kemampuan yang tinggi karena strain unggul baru tidak selalu ditemukan. Dalam berbagai pengembangan teknologi produksi enzim, pendekatan bioteknologi molekuler dan bioinformatika memiliki peranan yang sangat penting untuk memunculkan berbagai penemuan baru dalam bidang aplikasi enzim (Patel et al. 2017). Pengembangan strain mikrob unggul untuk mengoptimalkan produksi enzim berbabis pada berbagai karakter menguntungkan seperti halotoleran, ekstremofil, dan kemampuan memanfaatkan sumber karbon sederhana. Adanya berbagai kombinasi vektor, promotor dan penanda seleksi, serta kemajuan informasi terkait teknis fermentasi skala industri serta teknologi post-genomic memungkinkan dirancang sistem ekspresi enzim invertase yang lebih murah (Çelik and Çalık 2012). Nadeem et al. (2015) menyatakan bahwa pendekatan berbasis rekayasa genetika dengan aplikasi gen rekombinan sangat diperlukan untuk mendapatkan gen invertase yang memiliki aktivitas tinggi dalam mendegradasi gula. Terdapat dua cara utama dalam rekayasa enzim meliputi directed evolution dan rational design. Directed evolution merupakan pendekatan yang 
standard untuk produksi enzim pada industri makanan yang terdiri dari metode diversifikasi gen untuk menyusun mutation libraries; dan pendekatan screening serta seleksi yang efisien (FACS, ribosom display, dan $m R N A$ display). Selain itu, pendekatan rational design merupakan rekayasa yang berbasis pada informasi struktur gen, dan fungsi enzim (contoh: site-directed mutagenesis, dan restriction site cassette) (Hua et al. 2018). Pendekatan rekayasa genetika memungkinkan ditemukan strain mutan ataupun strain hasil trasformasi yang memiliki aktivitas fermentasi lebih tinggi, seperti $A$. niger Aw96-3 (43,90 IU mL $\left.{ }^{-1}\right)$ dan Aw96-4 (31,10 IU mL ${ }^{-1}$ ) (Montiel-gonzález et al. 2004), dan transforman Yarrowia lipolytica SUC+ yang mampu memproduksi enzim invertase hingga 43,25 IU mL $\mathrm{IL}^{-1}$ (Lazar et al. 2011). Yarrowia lipolytica digunakan karena mampu mengekspresikan heterologous proteins. Hal tersebut berhubungan dengan kemampuannya mensekresi protein dengan berat molekul yang besar dalam jumlah banyak. Protein disekresikan melalui cotranslational translocation pathway seperti yang terjadi pada sel eukariotik yang lebih tinggi, tidak melakukan fermentasi gula dan genomnya telah seluruhnya disekuensing dan terdata (Çelik dan Çalık 2012).Y. lipolytica yang pada mulanya tidak memiliki kemampuan untuk mengeskpresikan invertase dapat dimodifikasi sehingga mampu mengekspresikan enzim invertase (Lazar et al. 2011), dan dapat dilanjutkan pada tahap modifikasi untuk mendapat sifat over ekspresi (Lazar et al. 2011; Lazar et al. 2014; Liu et al. 2015). Veana et al. (2014) melakukan penyisipan gen invertase dari $A$. niger $\mathrm{GH} 1$ ke dalam methylotropic khamir Pichia pastoris. Pengunaan P. pastoris didasarkan pada kemampuan $P$. pastoris untuk tumbuh di medium yang memiliki komposisi yang lebih sederhana, mampu tumbuh secara cepat dan mampu memproduksi protein intraseluler atau ekstraseluler dalam jumlah tinggi. Marínnavarro et al. (2015) melaporkan aktivitas produksi enzim invertase yang lebih baik pada S. cerevisiae N21S dibandingkan dengan galur murni. S. cerevisiae N21S memiliki perubahan residu protein pada kompleks katalisnya yang dikonstruksi dengan pendekatan site-directed mutagenesis (Lafraya et al. 2011). Zhang et al. (2019) melaporkan modifikasi invertase yang berasal dari $S$. cerevisiae dengan substitusi residu hidrofilik di daerah situs aktif atau loop perifer dengan asam amino hidrofobik. Hal tersebut dilakukan untuk mengatur $\mathrm{pH}$ optimal dan kisaran stabilitas dalam mengkatalis pemecahan sukrosa menjadi glukosa dan fruktosa. Selain itu, invertase lain yang dimodifikasi secara genetik dengan aktivitas transfuktosilasi tinggi digunakan untuk produksi fruktooligosakarida prebiotik yang sederhana dan efisien.

Perkembangan teknologi biologi molekuler dan bioinformatika sejauh ini telah banyak digunakan dalam pengembangan enzim invertase, terutama invertase dari mikroorganisme (Manoochehri et al. 2020). Hal tersebut baik dilakukan karena pemanfaatan jasa mikroorganisme dalam produksi enzim atau aplikasi pemanfaatan enzim dalam sektor industri sejauh ini merupakan metode yang paling efisien untuk dilakukan. Sementara itu, pengembangan invertase dari tanaman juga tidak hanya dapat dimungkinkan untuk dilakukan dengan potensi aktivitas enzim yang lebih optimal. Pendekatan rekayasa genetika dalam kaitannya dengan mutagenesis protein, modifikasi protein, dan penyisipan gen invertase tanaman ke dalam mikroorganisme sangat mungkin untuk dilakukan. Selain itu, pengumpulan data struktur dan karakteristik enzim invertase tanaman yang sudah terkumpul sejauh ini dan yang akan datang dapat dijadikan sebagai salah satu landasan lain untuk memodifikasi struktur enzim invertase sehingga menghasilkan aktivitas yang optimum dengan kondisi lingkungan yang mudah untuk disesuaikan.

\section{Teknologi imobilisasi dan stabilisasi invertase} Seiring dengan dilakukan pengembangan strain, optimasi produksi enzim juga merupakan isu yang sangat penting dalam proses industri skala besar (Patel et al. 2016). Hal ini berhubungan dengan biaya produksi yang dikeluarkan sebagai faktor pembatas. Untuk mengurangi faktor pembatas tersebut dilakukan berbagai pengembangan teknologi imobilisasi enzim, dan teknologi aktivasi dan stabilisasi enzim seperti high hydrostatic pressure (Tribst dan Cristianini 2012), microwave (Elzobair et al. 2016; Marić et al. 2018), dan ultrasound 
(Dalagnol et al. 2017; Wang et al. 2018; de Souza Soares et al. 2019). Ultrasound merupakan teknologi yang dikembangkan untuk meningkatkan proses perpindahan panas dan massa dengan mengandalkan perambatan gelombang suara dengan frekuensi tinggi. Mekanisme ini dimanfaatkan untuk mengaktivasi atau inaktivasi enzim (Huang et al. 2017). Ultrasound dapat diaplikasikan sebagai pra-perlakuan terhadap enzim, terhadap substrat atau selama reaksi terjadi (campuran enzim dan substrat) untuk membantu reaksi (Wang et al. 2018). Microwave atau gelombang mikro merupakan sumber energi yang mampu menginduksi rotasi molekuler molekul dipolar dengan adanya medan elektromagnetik frekuensi tinggi $(2,45 \mathrm{GHz})$. Fenomena ini disertai dengan gesekan antar molekul dan penghamburan energi dengan pemanasan inti. Oleh karena enzim merupakan makromolekul yang peka terhadap suhu, aplikasi microwave memungkinkan untuk mengubah bentuk enzim sehingga mendapatkan biokatalis yang stabil dan efektif (Marić et al. 2018; de Souza Soares et al. 2019). Ertürk dan Meral (2019) melaporkan penggunaan stabilisasi enzim dengan microwave-based (MW) mampu meningkatkan konsentrasi protein dan meningkatkan aktivitas enzim. Aplikasi microwave merupakan tahap yang berlangsung dalam kondisi kering dan menggunakan energi secara efisien sehingga dapat terhindar dari resiko hilangnya protein akibat pencucian (Patil et al. 2016). Pada beberapa kasus seperti di dalam tanah, penggunaan microwave dengan suhu tinggi dapat merusak struktur enzim, sehingga penambahan bahan yang dapat meningkatkan stabilitas enzim menjadi sangat penting, seperti penggunaan biochar (Elzobair et al. 2015).

Sebagai molekul bebas yang larut dalam air, enzim sulit dipisahkan dari substrat dan produk, selain itu enzim sulit untuk digunakan secara berulang-ulang. Imobilisasi biasanya dapat dianggap sebagai perubahan enzim dari yang larut dalam air, keadaan bergerak menjadi keadaan tak bergerak yang tidak larut (Zhang et al. 2018). Imobilisasi mencegah difusi enzim ke dalam campuran reaksi dan mempermudah memperoleh kembali enzim tersebut dari aliran produk dengan teknik pemisahan padat atau cair yang sederhana (Hassan et al. 2016; Cacicedo et al. 2019). Imobilisasi enzim dapat dicapai dengan mengikat enzim secara kovalen ke permukaan bahan yang tak larut dalam air: pengikatan silang dengan bahan yang cocok untuk menghasilkan partikel yang baru; penjebakan di dalam suatu matrik atau gel yang permeabel terhadap enzim, substrat, dan produk; enkapsulasi; dan dengan absorbsi pada zat pendukung. Keuntungan imobilisasi enzim antara lain: memungkinkan penggunaan kembali enzim yang sudah pernah digunakan, ideal untuk proses berkelanjutan. Memungkinkan kontrol yang lebih akurat untuk proses katalisis, meningkatkan stabilitas enzim, dan memungkinkan pengambangan sistem reaksi multienzim (Patel et al. 2017).

Nanogels dapat digunakan sebagai material yang mampu mengimobilisasi enzim invertase. Nanoge/ tersebut terdiri dari methacrylic acid (MAAc), $N$-vinyl pyrrolidone (N-VP), dan ethyleneglycol dimethacrylate (EGDMA) yang disintesis dan dikonversi mengunakan metode emulsifikasi. Nanogel berperan dalam imobilisasi kovalen invertase S. cerevisiae (Raj et al. 2011). Sementara itu, jenis nanogel atau hydrogel yang digunakan berpengaruh terhadap efisiensi imobilisasi enzim invertase (Graebin et al. 2016; Cabrera et al. 2018). Mirzaei et al. (2013) melaporkan bahwa pengunaan chitosan sebagai hydrogel memiliki efisiensi 95\%, sementara pengunaan gelatin memiliki efisiensi $85 \%$ dan poly-acrylamide $75 \%$. Andjelkovic et al. (2015) melakukan penelitian imobilasi enzim invertase mengunakan beidellite nanoclay yang terbukti mampu meningkatkan stabilitas thermal dan penyimpanan enzim, sehingga dapat digunakan sebagai bahan yang ditambahkan untuk imobilisasi enzim dengan harga yang relatif lebih murah. Cabrera et al. (2017) telah melakukan penelitian terkait pengunaan magnetik diatomaceous untuk mengimobilisasi enzim invertase dengan hasil yang positif. Sebelumnya, Azodi et al. (2011) melaporkan pemanfaatan bahan silikon berpori (porous silicon) dalam tahap imobilisasi enzim invertase. Meskipun afinitas enzim mengalami penurunan setelah imobilisasi, nilai $V_{\max }$ meningkat secara signifikan hingga $30 \%$. Albertini et al. (2013) melaporkan pengunaan abu dari batubara yang 
mengandung Glass-ceramic zinc sulfate mampu mengimobilisasi enzim invertase secara kovalen dan dengan penurunan kehilangan invertase hanya 9\% dari aktivitas semula. Waifalkar et al. (2016) mengembangkan pengunaan chitosan yang telah dilapisi dengan magnetik nanopartikel (MNPs) dan terbukti berhasil mengimobilisasi enzim invertase dan meningkatkan aktivitas dan stabilitas enzim tersebut. Invertase yang terimobilisasi pada MNPs memiliki aktivitas dan stabilitas yang jauh lebih tinggi dibandingkan dengan aktivitas invertase bebas pada berbagai variasi $\mathrm{pH}$ dan suhu. Selain pengembangan teknik imobilisasi enzim, imobilisasi juga dikembangkan pada sel khamir yang menghasilkan enzim invertase. Yildiz et al. (2013) mengembangkan pemanfaatkan elektroda poly(ethyleneoxide) membandingkan imobilisasi enzim invertase dengan imobilisasi sel khamir yang memproduksi enzim tersebut. Aplikasi imobilisasi sel khamir dinilai lebih potensial untuk skala industri secara ekonomi meskipun enzim yang digunakan bukan enzim yang telah terpurifikasi. Meskipun invertase merupakan enzim dengan nilai komersil yang tinggi, nilai ekonomis enzim invertase relatif rendah dibandingkan dengan enzim lain. Hal tersebut dikarenakan meskipun enzim invertase banyak digunakan di dalam berbagai aplikasi seperti dunia kesehatan dan sektor energi, sebagian besar pemanfaatannya lebih banyak pada industri makanan dan olahan minuman, sehingga pemanfaatan enzim dengan jumlah banyak dan harga murah sangat dibutuhkan. Selain itu, enzim secara umum lebih mudah mengalami degradasi karena $\mathrm{pH}$, suhu, dan pengadukan pada skala industri dengan skala produksi yang relatif besar.

\section{KESIMPULAN}

Enzim invertase yang diisolasi dari tanaman membentuk dua klaster yaitu cell wall invertase dan vacuolar invertase. Keduanya memiliki hubungan filogenetik paling jauh dibandingkan dengan invertase dari khamir dan invertase dari bakteri. Perbedaan informasi genetik tersebut menghasilkan potensi aktivitas invertase yang berbeda. Enzim invertase dari khamir pada umumnya memiliki aktivitas yang relatif lebih tinggi dibandingkan invertase dari bakteri. Selain itu, aktivitas invertase dari tanaman yang berhasil diisolasi ditemukan memiliki aktivitas yang lebih tinggi dibandingkan invertase dari bakteri maupun khamir, meskipun pemanfaatannya dalam industri masih jarang dilakukan. Dengan pendekatan rekayasa genetika, potensi enzim invertase dari tanaman mungkin dilakukan dengan mengekspresikan gen invertase tanaman pada mikrobia yang menguntungkan secara operasional produksinya. Hal tersebut membuat pendekatan rekayasa genetik dengan merekombinasikan gen invertase pada tanaman ke dalam mikrobia patut dikembangkan disamping pengembangan eksplorasi demi mendapatkan novel invertase yang memiliki aktivitas tinggi.

Pengembangan metode produksi enzim invertase dalam skala industri sejauh ini didasarkan bagaimana meningkatkan aktivitas enzim invertase. Hal tersebut dilakukan melalui imobilisasi enzim yang dilakukan dengan berbagai pengembangan pemanfaatan bahan pengimobilisasi baru termasuk partikel nano; serta peningkatan stabilitas enzim dengan didukung oleh berbagai pengembangan teknologi yang sejauh ini telah dikembangkan seperti high hydrostatic pressure, microwave, dan ultrasound. Pengembangan aspek-aspek tersebut dilakukan dan secara langsung juga berhubungan dengan aspek produksi enzim lainnya seperti penggunaan substrat yang lebih murah dan penurunan resiko kontaminasi. Dengan kata lain, pengembangan teknologi produksi enzim dan pemanfaatannya di bidang industri sangat erat kaitannya dengan usaha mendapatkan proses produksi yang seefisien mungkin dengan biaya yang rendah.

\section{DAFTAR PUSTAKA}

Aita BC, Spannemberg SS, Schmaltz S, Zabot GL, Tres MV, Kuhn RC, Mazutti MA (2019) Production of cell-wall degrading enzymes by solid-state fermentation using agroindustrial residues as substrates. J Environ Chem Eng 7:103193. doi: 10.1016/j.jece.2019.103193

Albertini AVP, Silva JL, Freire VN, Santos RP, Martins JL, Cavada BS, Cadena PG, 
Neto PJR, Pimentel MCB, Martínez CR, Porto ALF, Filho JLL (2013) Immobilized invertase studies on glassceramic support from coal fly ashes. Chem Eng J 214:91-96. doi: 10.1016/j.cej.2012.10.029

Alegre ACP, Polizeli MLTM, Terenzi HF, Jorge JA, Guimarães LHS (2009) Production of thermostable invertases by Aspergillus caespitosus under submerged or solid state fermentation using agroindustrial residues as carbon source. Braz J Microbiol 40:612-622. doi: 10.1590/S1517-838220090003000025

Alves JN, Jorge JA, Guimarães LHS (2013) Production of invertases by anamorphic (Aspergillus nidulans) and teleomorphic (Emericela nidulans) fungi under submerged fermentation using rye flour as carbon source. Adv Microbiol 2013:421429. doi: 10.4236/aim.2013.35057

Andjelkovic U, Milutinovic-Nikolic A, JovicJovicic N, Bankovic P, Bajt T, Mojovic Z, Vujcic Z, Jovanovic D (2015) Efficient stabilization of Saccharomyces cerevisiae external invertase by immobilisation on modified beidellite nanoclays. Food Chem 168:262-269 doi: 10.1016/j.foodchem.2014.07.055

Aranda C, Robledo A, Loera O, ContrerasEsquivel JC, Rodríguez R, Aguilar CN (2006) Fungal invertase expression in solid-state fermentation. Food Technol Biotechnol 44:229-233

Awad GEA, Amer H, El-Gammal EW, Helmy WA, Esawy MA, Elnashar MMM (2013) Production optimization of invertase by Lactobacillus brevis $\mathrm{Mm}-6$ and its immobilization on alginate beads. Carbohydr Polym 93:1-37. doi: 10.1016/j.carbpol.2012.12.039

Azodi M, Falamaki C, Mohsenifar A (2011) Sucrose hydrolysis by invertase immobilized on functionalized porous silicon. J Mol Catal B Enzym 69:154-160. doi: 10.1016/j.molcatb.2011.01.011

Badr HR, Sims KA, Adams MWW (1994) Purification and characterization of sucrose $\alpha$-glucohydrolase (invertase) from the hyperthermophilic archaeon Pyrococcus furiosus. Syst Appl Microbiol 17:1-6. doi: 10.1016/S07232020(11)80023-8

Billett EE, Billett MA, Burnett JH (1977) Stimulation of maize invertase activity following infection by Ustilago maydis. Phytochemistry 16:1163-1166. doi: 10.1016/S0031-9422(00)94352-8

Borghi DF, Guirardello R, Fllho LC (2009) Storage logistics of fruits and vegetables: effect of temperature. Chem Eng Trans 17:952-956. doi: 10.3303/CET0917159

Brown AJ (1902) Enzyme Action. J Chem Soc Trans 81:373-388. doi: 10.1039/CT9028100373

Brummell DA, Chen RKY, Harris JC, Zhang $\mathrm{H}$, Hamiaux C, Kralicek AV, Mckenzie MJ (2011) Induction of vacuolar invertase inhibitor mRNA in potato tubers contributes to cold-induced sweetening resistance and includes spliced hybrid mRNA variants. J Exp Bot 62:35193534. doi: 10.1093/jxb/err043

Cabrera MÁ, Blamey JM (2018) Biotechnological applications of archaeal enzymes from extreme environments. Biol Res 51:37. doi: 10.1186/s40659-018-0186-3

Cabrera MP, Assis CRD, Neri DFM, Pereira CF, Soria F, Carvalho LB (2017) High sucrolytic activity by invertase immobilized onto magnetic diatomaceous earth nanoparticles. Biotechnol Rep (Amst) 14:38-46. doi: 10.1016/j.btre.2017.03.001

Cabrera MP, da Foseca TF, Varela R, de Souza RVB, de Assis CRD, Marcatoma JQ, de Costa Maciel J, Neri DFM, Soria F, de Carvalho Jr LB (2018) Polyanilinecoated magnetic diatomite nanoparticles as a matrix for immobilizing enzymes. Appl Surf Sci 457:21-29. doi: 10.1016/j.apsusc.2018.06.238

Cacicedo ML, Manzo RM, Municoy S, Bonazza $\mathrm{HL}$, Islan $\mathrm{GA}$, Desimone $\mathrm{M}$, Bellino M, Mammarella EJ, Castro GR (2019) Ch 7 - Immobilized enzymes and their applications. Adv Enzyme Technol 2019:169-200. doi: 10.1016/B978-0444-64114-4.00007-8

Carneiro AAJ, Giese EC, Barbosa AM, Gomes E, Da Silva R (2011) Agaricus blazei as a substrate for the production of $\beta-1,3-G l u c a n a s e$ by Trichoderma harzianum Rifai. Food Technol Biotechnol 49:341-346

Çelik E, Çalık P (2012) Production of recombinant proteins by yeast cells. Biotechnol Adv 30:1108-1118. doi: 
10.1016/j.biotechadv.2011.09.011

Chand Bhalla T, Bansuli, Thakur N, Savitri, Thakur N (2017) Invertase of Saccharomyces cerevisiae SAA-612: Production, characterization and application in synthesis of fructooligosaccharides. LWT 77:178-185. doi: 10.1016/j.Iwt.2016.11.034

Chavez FP, Rodriguez L, Diaz J, Delgado JM, Cremata JA (1997) Purification and characterization of an invertase from Candida utilis: Comparison with natural and recombinant yeast invertases. J Biotechnol 53:67-74. doi: 10.1016/s0168-1656(97)01663-5

Chen Z, Gao K, Su X, Rao P, An X (2015) Genome-wide identification of the invertase gene family in populus. PLoS One 10:e0138540. doi: 10.1371/journal.pone. 0138540

Dalagnol LMG, Silveira VCC, da Silva HB, Manfroi V, Rodrigues RC (2017) Improvement of pectinase, xylanase and cellulase activities by ultrasound: Effects on enzymes and substrates, kinetics and thermodynamic parameters. Process Biochem 61:8087. doi: 10.1016/j.procbio.2017.06.029

de Gines SC, Maldonado MC, de Valdez GF (2000) Purification and characterization of invertase from Lactobacillus reuteri CRL 1100. Curr Microbiol 40:181-184. doi: $10.1007 / \mathrm{s} 002849910036$

de Oliveira Rodrigues $P$, Gurgel LVA, Pasquini D, Badotti F, Goes-Neto A, Baffi MA (2020) Lignocellulosedegrading enzymes production by solidstate fermentation through fungal consortium among Ascomycetes and Basidiomycetes. Renew Energy 145:2683-2693. doi: 10.1016/j.renene.2019.08.041

de Souza Soares A, Augusto PED, de Castro Leite Júnior BR, Nogueira CA, Vieira ÉNR, de Barros FAR, Stringheta PC, Ramos AM (2019) Ultrasound assisted enzymatic hydrolysis of sucrose catalyzed by invertase: Investigation on substrate, enzyme and kinetics parameters. LWT 107:164-170. doi: 10.1016/j.Iwt.2019.02.083

Dipasquale L, Gambacorta A, Siciliano RA, Mazzeo MF, Lama L (2009) Purification and biochemical characterization of a native invertase from the hydrogen- producing Thermotoga neapolitana (DSM 4359). Extremophiles 13:345354. doi: 10.1007/s00792-008-0222-2

Du L, Pang H, Wang Z, Lu J, Wei Y, Huang R (2013) Characterization of an invertase with $\mathrm{pH}$ tolerance and truncation of its $\mathrm{N}$-terminal to shift optimum activity toward neutral $\mathrm{pH}$. PLoS One 8:e62306. doi: 10.1371/journal.pone.0062306

Ebaid R, Wang $\mathrm{H}$, Sha $\mathrm{C}$, Abomohra AE, Shao W (2019) Recent trends in hyperthermophilic enzymes production and future perspectives for biofuel industry: A critical review. J Clean Prod 238:117925. doi: 10.1016/j.jclepro.2019.117925

Elzobair KA, Stromberger ME, Ippolito JA (2016) Stabilizing effect of biochar on soil extracellular enzymes after a denaturing stress. Chemosphere 142:114-119. doi: 10.1016/j.chemosphere.2015.03.018

Ertürk B, Meral R (2019) The impact of stabilization on functional, molecular and thermal properties of rice bran. $\mathrm{J}$ Cereal Sci 88:71-78. doi: 10.1016/j.jcs.2019.05.011

Fils-Lycaon B, Julianus P, Chillet M, Galas C, Hubert O, Rinaldo D, Mbéguié-AMbéguié $D$ (2011) Acid invertase as a serious candidate to control the balance sucrose versus (glucose + fructose) of banana fruit during ripening. Sci Hortic (Amsterdam) 129:197-206. doi: 10.1016/j.scienta.2011.03.029

Fotopoulos V (2005) Plant invertases: structure, function and regulation of a diverse enzyme family. J Biol Res $4: 127-137$

Giraldo MA, da Silva TM, Salvato F, Terenzi HF, Jorge JA, Guimaraes LHS (2012) Thermostable invertases from Paecylomyces variotii produced under submerged and solid-state fermentation using agroindustrial residues. World $\mathrm{J}$ Microbiol Biotechnol 28:463-472. doi: 10.1007/s11274-011-0837-9

Girelli AM, Astolfi ML, Scuto FR (2020) Agroindustrial wastes as potential carriers for enzyme immobilization: A review. Chemosphere 244:125368. doi: 10.1016/j.chemosphere.2019.125368

Graebin NG, Schoffer JN, de Andrades D, Hertz PF, Ayub MAZ, Rodrigues RC (2016) Immobilization of glycoside hydrolase families $\mathrm{GH} 1, \mathrm{GH} 13$ and 
GH70: State of the art and perspectives. Molecules 21: 1074. doi: 10.3390/molecules21081074

Guo PC, Wang Q, Wang Z, Dong Z, He H, Zhao $P$ (2018) Biochemical characterization and functional analysis of invertase Bmsuc1 from silkworm, Bombyx mori. Int J Biol Macromol 107:2334-2341. doi: 10.1016/j.jijbiomac.2017.10.118

Hassan ME, Tamer TM, Omer AM (2016) Methods of enzyme immobilization. Int J Curr Pharm Rev Res 7:385-392

Heslot H, Gaillardin C (1992) Molecular Biology and Genetic Engineering of Yeasts. CRC Press, Florida USA. doi: 10.1201/9781351074735

Hoffmann JJ, Hövels M, Kosciow K, Deppenmeier U (2020) Synthesis of the alternative sweetener 5-ketofructose from sucrose by fructose dehydrogenase and invertase producing Gluconobacter strains. J Biotechnol 307:164-174. doi: 10.1016/j.jbiotec.2019.11.001

Hua W, EI Sheikha AF, Xu J (2018) Molecular techniques for making recombinant enzymes used in food processing. Pp 95-109. In: El Sheikha AF, Levin R, Xu $\mathrm{J}$ (eds) Molecular Techniques in Food Biology: Safety, Biotechnology, Authenticity and Traceability. John Wiley \& Sons, New Jersey USA. doi: 10.1002/9781119374633.ch5

Huang G, Chen S, Dai C, Sun L, Sun W, Tang $\mathrm{Y}$, Xiong F, He R, Ma H (2017) Effects of ultrasound on microbial growth and enzyme activity. Ultrason Sonochem 37:144 149. doi: 10.1016/j.ultsonch.2016.12.018

Hussain A, Rashid MH, Perveen R, Ashraf M (2009) Purification, kinetic and thermodynamic characterization of soluble acid invertase from sugarcane (Saccharum officinarum L.). Plant Physiol Biochem 47:188-194. doi: 10.1016/j.plaphy.2008.11.001

Isla MI, Vattuone MA, Ordonez RM, Sampietro AR (1999) Invertase activity associated with the walls of Solanum tuberosum tubers. Phytochemistry 50:525-534. doi: 10.1016/s00319422(98)00474-9

Jana A, Maity C, Halder SK, Das A, Pati BR, Mondal KC, Mohapatra PKD (2013) Structural characterization of thermostable, solvent tolerant, cytosafe tannase from Bacillus subtilis PAB2.
Biochem Eng J 77:161-170. doi: 10.1016/j.bej.2013.06.002

Khootama A, Putri DN, Hermansyah H (2018) Techno-economic analysis of lipase enzyme production from Aspergillus niger using agro-industrial waste by solid state fermentation. Energy Procedia 153:143-148. doi: 10.1016/j.egypro.2018.10.054

Kim JY, Mahe A, Guy S, Brangeon J, Roche O, Chourey PS, Prioul JL (2000) Characterization of two members of the maize gene family, Incw3 and Incw4, encoding cell-wall invertases. Gene 245:89-102. doi: 10.1016/s03781119(00)00034-2

Krishnan HB, Pueppke SG (1990) Cherry fruit invertase: Partial purification, characterization and activity during fruit development. J Plant Physiol 135:662$666 . \quad$ doi: 10.1016/S01761617(11)80876-X

Kulshrestha S, Tyagi P, Sindhi V, Yadavilli KS (2013) Invertase and its applications - A brief review. J Pharm Res 7:792-797. doi: 10.1016/j.jopr.2013.07.014

L'Hocine L, Wang Z, Jiang B, Xu S (2000) Purification and partial characterization of fructosyltransferase and invertase from Aspergillus niger AS0023. J Biotechnol 81:73-84. doi: 10.1016/S0168-1656(00)00277-7

Lafraya A, Sanz-Aparicio J, Polaina J, MarínNavarro J (2011) Fructo-oligosaccharide synthesis by mutant versions of Saccharomyces cerevisiae invertase. Appl Environ Microbiol 77:6148-6157. doi: 10.1128/AEM.05032-11

Lazar Z, Dulermo T, Neuvéglise C, Coq AC, Nicaud JM (2014) Hexokinase - A limiting factor in lipid production from fructose in Yarrowia lipolytica. Metab Eng 26:89-99. doi: 10.1016/j.ymben.2014.09.008

Lazar Z, Walczak E, Robak M (2011) Simultaneous production of citric acid and invertase by Yarrowia lipolytica $\mathrm{SUC}^{+}$transformants. Bioresour Technol 102:6982-6989. doi: 10.1016/j.biortech.2011.04.032

Leal DP, Isla MI, Vattuone MA, Sampietro AR (1999) A hysteretic invertase from Equisetum giganteum L. Phytochem 52:1009-1016. doi: 10.1016/S00319422(99)00313-1 
Leite P, Silva C, Salgado JM, Belo I (2019) Simultaneous production of lignocellulolytic enzymes and extraction of antioxidant compounds by solid-state fermentation of agro-industrial wastes. Industrial Crops \& Products 137:315-322. doi: 10.1016/j.indcrop.2019.04.044

Li Q, Al Loman A, Callow NV, Islam SMM, Ju LK (2018) Leveraging $\mathrm{pH}$ profiles to direct enzyme production (cellulase, xylanase, polygalacturonase, pectinase, $\alpha$-galactosidase, and invertase) by Aspergillus foetidus. Biochem Eng J 137:247-254. doi: 10.1016/j.bej.2018.06.008

Lin Q, Wang S, Wang M, Cao R, Zhang R, Zhan R, Wang K (2019) A novel glycoside hydrolase family 42 enzyme with bifunctional $\beta$-galactosidase and $\alpha$ L-arabinopyranosidase activities and its synergistic effects with cognate glycoside hydrolases in plant polysaccharides degradation. Int $\mathrm{J}$ Biol Macromol 140:129-139. doi: 10.1016/j.jibiomac.2019.08.037

Liu $\mathrm{HH}$, Ji XJ, Huang $\mathrm{H}$ (2015) Biotechnological applications of Yarrowia lipolytica: Past, present and future. Biotechnol Adv 33:1522-1546. doi: 10.1016/j.biotechadv.2015.07.010

Liu X, Jiang Z, Ma S, Yan Q, Chen Z, Liu H (2020) High-level production and characterization of a novel $\beta-1,3-1,4$ glucanase from Aspergillus awamori and its potential application in the brewing industry. Process Biochem 92:252-260. doi: 10.1016/j.procbio.2020.01.017

Lorenzoni ASG, Aydos LF, Klein MP, Rodrigues RC, Hertz PF (2014) Fructooligosaccharides synthesis by highly stable immobilized $\beta$ fructofuranosidase from Aspergillus aculeatus. Carbohydr Polym 103:193197. doi: 10.1016/j.carbpol.2013.12.038

Manoochehri H, Hosseini NF, Saidijam M, Taheri M, Rezaee H, Nouri F (2020) A review on invertase: Its potentials and applications. Biocatal Agric Biotechnol 25:101599. doi: 10.1016/j.bcab.2020.101599

Marić M, Grassino AN, Zhu Z, Barba FJ, Brnčić M, Brnčić SR (2018) An overview of the traditional and innovative approaches for pectin extraction from plant food wastes and by-products: Ultrasound-, microwaves-, and enzyme-assisted extraction. Trends Food Sci Technol 76:28-37. doi: 10.1016/j.tifs.2018.03.022

Marín-Navarro J, Talens-Perales D, Polaina J (2015) One-pot production of fructooligosaccharides by a Saccharomyces cerevisiae strain expressing an engineered invertase. Appl Microbiol Biotechnol 99:25492555. doi: 10.1007/s00253-014-6312-4

Metzenberg RL, Chandler SH, Ger- W (1963) The Purification and properties of invertase of Neurospora. Arch Biochem Biophys 100:503-511. doi: 10.1016/0003-9861(63)90118-8

Mirzaei EB, Ramazani ASA, Shafiee M, Danaei M (2013) Studies on glutaraldehyde crosslinked chitosan hydrogel properties for drug delivery systems. Int $\mathrm{J}$ Polym Biomater 62:605-611. doi: 10.1080/00914037.2013.769165

Molaverdi M, Karimi K, Mirmohamadsadeghi S, Galbe M (2019) High titer ethanol production from rice straw via solidstate simultaneous saccharification and fermentation by Mucor indicus at low enzyme loading. Energy Conversion Manage 182:520-529. doi: 10.1016/j.enconman.2018.12.078

Montiel-González AM, Viniegra-González G, Fernández FJ, Loera O (2004) Effect of water activity on invertase production in solid state fermentation by improved diploid strains of Aspergillus niger. Process Biochem 39:2085-2090. doi: 10.1016/j.procbio.2003.10.013

Morsy FM, Ibrahim SH (2016) Concomitant hydrolysis of sucrose by the long halflife time yeast invertase and hydrogen production by the hydrogen overproducing Escherichia coli HD701. Energy 109:412-419. doi: 10.1016/j.energy.2016.05.006

Nadeem H, Rashid MH, Siddique MH, Azeem F, Muzammil S, Javed MR, Ali MA, Rasul I, Riaz M (2015) Microbial invertases: A review on kinetics, thermodynamics, physiochemical properties. Process Biochem 50:1202-1210. doi: 10.1016/j.procbio.2015.04.015

Nguyen TY, Cai CM, Osman O, Kumar R, Wyman CE (2016) CELF pretreatment of corn stover boosts etanol titers and yields from high solids SSF with low enzyme loadings. Green Chem 18:1581-1589. 
doi: 10.1039/C5GC01977J

Ohara A, de Castro RJS, Nishide TG, Dias FFG, Bagagli MP, Sato HH (2015) Invertase production by Aspergillus niger under solid state fermentation: Focus on physical-chemical parameters, synergistic and antagonistic effects using agroindustrial wastes. Biocatal Agric Biotechnol 4:645-652. doi: 10.1016/j.bcab.2015.06.008

Oyedeji O, Bakare MK, Adewale IO, Olutiola PO, Omoboye OO (2017) Optimized production and characterization of thermostable invertase from Aspergillus niger IBK1, using pineapple peel as alternate substrate. Biocatal Agric Biotechnol 9:218-223. doi: 10.1016/j.bcab.2017.01.001

Pan Y-Q, Luo H-L, Li Y-R (2009) Soluble acid invertase and sucrose phosphate synthase: Key enzymes in regulating sucrose accumulation in sugarcane stalk. Sugar Tech 11:28-33. doi: 10.1007/s12355-009-0005-9

Pancoast HM, Junck WR (1981) Handbook of Sugars, Second Edition. AVI Publishing Company, Inc., Westport, Connecticut. doi: 10.1002/star.19810330613

Patel AK, Singhania RR, Pandey A (2016) Novel enzymatic processes applied to the food industry. Curr Opin Food Sci 7:64-72. doi: 10.1016/j.cofs.2015.12.002

Patel AK, Singhania RR, Pandey A (2017) Chapter 2 - Production, purification, and application of microbial enzymes. Pp 13-41. In Brahmachari $G$, Demain $A L$, Adrio JL (Eds.) Biotechnology of Microbial Enzymes: Production, Biocatalysis and Industrial Application. Elsevier, UK. doi: 10.1016/B978-0-12803725-6.00002-9

Patil SS, Kar A, Mohapatra D (2016) Stabilization of rice bran using microwave: Process optimization and storage studies. Food Bioprod Process 99:204-211. doi: 10.1016/j.fbp.2016.05.002

Perez CL, Casciatori FP, Thomeo JC (2019) Strategies for scaling-up packed-bed bioreactors for solid-state fermentation: The case of cellulolytic enzymes production by a thermophilic fungus. Chem Eng J 361:1142-1151. doi: 10.1016/j.cej.2018.12.169

Plascencia-Espinosa M, Santiago-
Hernandez A, Pavon-Orozco P, VallejoBecerra V, Trejo-Estrada S, SosaPeinado A, Benitez-Cardoza CG, Hidalgo-Lara ME (2014) Effect of deglycosylation on the properties of thermophilic invertase purified from the yeast Candida guilliermondii Mpllla. Process Biochem 49:1480-1487. doi: 10.1016/j.procbio.2014.05.022

Rahman $\mathrm{MH}$, Akand $\mathrm{AAH}$, Yeasmin T, Uddin MS, Rahman M (2001) Purification and properties of invertase from mango fruit. Pak J Biol Sci 4:1271-1274. doi: 10.3923/pjbs.2001.1271.1274

Rahman SM, Sen PK, Hasan MF, Miah MAS, Rahman MH (2004) Purification and characterization of invertase enzyme from sugarcane. Pak J Biol Sci 7:340345. doi: 10.3923/pjbs.2004.340.345

Raj L, Chauhan GS, Azmi W, Ahn JH, Manuel J (2011) Kinetics study of invertase covalently linked to a new functional nanogel. Bioresour Technol 102:21772184. doi: 10.1016/j.biortech.2010.11.062

Raju A, Pulipati K, Jetti A (2016) Production of invertase by Aspergillus niger under solid state fermentation using orange fruit peel as substrate. Adv Crop Sci Tech 4:247. doi: 10.4172/23298863.1000247

Ranwala AP, Suematsu C, Masuda H (1992) Soluble and wall-bound invertases in strawberry fruit. Plant Sci 84:59-64. doi: 10.1016/0168-9452(92)90208-4

Romero-Gomez SJ, Augur C, ViniegraGonzález G (2000) Invertase production by Aspergillus niger in submerged solid-state fermentation. Biotechnol Lett 22:1255-1258. doi: 10.1023/A:1005659217932

Ruan YL, Jin Y, Yang YJ, Li GJ, Boyer JS (2010) Sugar input, metabolism, and signaling mediated by invertase: Roles in development, yield potential, and response to drought and heat. Mol Plant 3:942-955. doi: $10.1093 / \mathrm{mp} / \mathrm{ssq} 044$

Rubio MC, Runco R, Navarro AR (2002) Invertase from a strain of Rhodotorula glutinis. Phytochem 61:605-609. doi: 10.1016/S0031-9422(02)00336-9

Rustiguel CB, Terenzi HF, Jorge JA, Guimarães LHS (2010) A novel silveractivated extracellular $\quad \beta$-Dfructofuranosidase from Aspergillus phoenicis. J Mol Catal B Enzym 67:10- 
15. doi: 10.1016/j.molcatb.2010.06.012

Ryan SM, Fitzgerald GF, van Sinderen D (2005) Transcriptional regulation and characterization of a novel $\beta$ fructofuranosidase-encoding gene from Bifidobacterium breve UCC2003. Appl Environ Microbiol 71:3475-3482. doi: 10.1128/AEM.71.7.3475-3482.2005

Singh R, Kumar M, Mittal A, Kumar P (2016) Microbial enzymes: industrial progress in 21 st century. 3 Biotech 6:174. doi: 10.1007/s13205-016-0485-8

Singh RS, Chauhan K, Kaur K, Pandey A (2020) Statistical optimization of solidstate fermentation for the production of fungal inulinase from apple pomace. Bioresour Technol Reports 9:100364. doi: 10.1016/j.biteb.2019.100364

Sum WF, Rogers PJ, Jenkins ID, Guthrie RD (1980) Isolation of invertase from banana fruit (Musa cavendishii). Phytochemistry 19:399-401. doi: 10.1016/0031-9422(80)83188-8

Taliercio EW, Kim JY, Mahe A, Shanker S, Chi J, Cheng WH, Prioul JL, Chourey PS (1999) Isolation, characterization and expression analyses of two cell wall invertase genes in maize. J Plant Physiol 155:197-204. doi: 10.1016/S0176-1617(99)80007-8

Taskin M, Esim N, Genisel M, Ortucu S, Hasenekoglu I, Canli O, Erdal S (2013) Enhancement of invertase production by Aspergillus niger OZ-3 using lowintensity static magnetic fields. Prep Biochem Biotechnol 43:177-188. doi: 10.1080/10826068.2012.713431

Taskin M, Ortucu S, Unver Y, Tasar OC, Ozdemir M, Kaymak HC (2016) Invertase production and molasses decolourization by cold-adapted filamentous fungus Cladosporium herbarum ER-25 in non-sterile molasses medium. Process Safety Environ Prot 103:136-143. doi: 10.1016/j.psep.2016.07.006

Tribst AAL, Cristianini M (2012) Increasing fungi amyloglucosidase activity by high pressure homogenization. Innov Food Sci Emerg Technol 16:21-25. doi: 10.1016/j.ifset.2012.03.002

Uma C, Gomathi D, Muthulakshmi C, Gopalakrishnan VK (2010) Production, purification and characterization of invertase by Aspergillus flavus using fruit peel waste as substrate. Adv Biol Res (Rennes) 4:31-36

Uma C, Gomathi D, Ravikumar G, Kalaiselvi M, Palaniswamy M (2012) Production and properties of invertase from a Cladosporium cladosporioides in $\mathrm{SmF}$ using pomegranate peel waste as substrate. Asian Pac J Trop Biomed 2:S605-S611. doi: 10.1016/S22211691(12)60282-2

Veana F, Fuentes-Garibay JA, Aguilar CN, Rodríguez-Herrera R, GuerreroOlazarán M, Viader-Salvadó JM (2014) Gene encoding a novel invertase from a xerophilic Aspergillus niger strain and production of the enzyme in Pichia pastoris. Enzyme Microb Technol 63:28-33. doi: 10.1016/j.enzmictec.2014.05.001

Vorster DJ, Botha FC (1998) Partial purification and characterization of sugarcane neutral invertase. Phytochem 49:651-655. doi: 10.1016/S0031-9422(98)00204-0

Waifalkar PP, Parit SB, Chougale AD, Sahoo SC, Patil PS, Patil PB (2016) Immobilization of invertase on chitosan coated $\gamma-\mathrm{Fe}_{2} \mathrm{O}_{3}$ magnetic nanoparticles to facilitate magnetic separation. J Colloid Interface Sci 482:159-164. doi: 10.1016/j.jcis.2016.07.082

Wan E, Akana M, Pons J, Chen J, Musone S, Kwok P-Y, Liao W (2010) Green technologies for room temperature nucleic acid storage. Curr Issues Mol Biol 12:135-142. PMID: 19801719

Wan H, Wu L, Yang Y, Zhou G, Ruan Y (2018) Evolution of sucrose metabolism: The dichotomy of invertases and beyond. Trends Plant Sci 23:163-177. doi: 10.1016/j.tplants.2017.11.001

Wang D, Yan L, Ma X, Wang W, Zou M, Zhong J, Ding T, Ye X, Liu D (2018) Ultrasound promotes enzymatic reactions by acting on different targets: Enzymes, substrates and enzymatic reaction systems. Int $\mathrm{J}$ Biol Macromol 119:453-461. doi: 10.1016/j.jibiomac.2018.07.133

Wang J, Nayak S, Koch K, Ming R (2013) Carbon partitioning in sugarcane (Saccharum species). Front Plant Sci 4:201. doi: 10.3389/fpls.2013.00201

Wang L, Zheng Y, Ding S, Zhang Q, Chen Y, Zhang J (2017) Molecular cloning, structure, phylogeny and expression 
analysis of the invertase gene family in sugarcane. BMC Plant Biol 17:109. doi: 10.1186/s12870-017-1052-0

Warchol M, Perrin S, Grill J-P, Schneider F (2002) Characterization of a purified $\beta$ fructofuranosidase from Bifidobacterium infantis ATCC 15697. Lett Appl Microbiol 35:462-467. doi: 10.1046/j.1472-765X.2002.01224.x

Win TT, Isono N, Kusnadi Y, Watanabe K, Obae $\mathrm{K}$, Ito $\mathrm{H}$, Matsui $\mathrm{H}$ (2004) Enzymatic synthesis of two novel non-reducing oligosaccharides using transfructosylation activity with $\beta$-fructofuranosidase from Arthrobacter globiformis. Biotechnol Lett 26:499-503. doi: 10.1023/b:bile.0000019557.44196.63

Xue J, Tang Y, Wang S, Yang R, Xue Y, Wu $C$, Zhang $X$ (2018) Assessment of vase quality and transcriptional regulation of sucrose transporter and invertase genes in cut peony (Paeonia lactiflora 'Yang Fei Chu Yu') treated by exogenous sucrose. Postharvest Biol Technol 143:92-101. doi: 10.1016/j.postharvbio.2018.04.014

Yamamoto K, Kitamoto Y, Ohata N, Isshiki S, Ichikawa $Y$ (1986) Purification and properties of invertase from a glutamate-producing bacterium. J Ferment Technol 64:285-291. doi:
10.1016/0385-6380(86)90120-2

Yildiz HB, Kamaci M, Azak H, Secgin O, Suer O (2013) A comparative study: Immobilization of yeast cells and invertase in poly(ethyleneoxide) electrodes. J Mol Catal B Enzym 91:5258. doi: 10.1016/j.molcatb.2013.02.009

Yoon M-H, Choi W-Y, Kwon S-J, Yi S-H, Lee D-H, Lee J-S (2007) Purification and properties of intracelluler invertase from alkalophilic and thermophilic Bacillus cereus TA-11. J Appl Blol Chem 50:196-201

Zhang W, Ruirui L, Ai X, Chen J, Xu W, Li W, Ai Y (2018) Enzyme activity and microbial biomass availability in artificial soils on rock-cut slopes restored with outside soil spray seeding (OSSS): Influence of topography and season. $\mathrm{J}$ Environ Manage 211:287-295. doi: 10.1016/j.jenvman.2018.01.005

Zhang Y, Geary T, Simpson BK (2019) Genetically modified food enzymes:A review. Curr Opin Food Sci 25:14-18. doi: 10.1016/j.cofs.2019.01.002

Zhang YL, Zhang AH, Jiang J (2013) Gene expression patterns of invertase gene families and modulation of the inhibitor gene in tomato sucrose metabolism. Genet Mol Res 12:3412-3420. doi: 10.4238/2013.january.24.1 